\title{
Karakterisasi Protease Ekstraseluler Clostridium spp. T11-3
}

\section{The Characterization of Extracellular Protease Clostridium spp. T11- 3}

\author{
Loli Natalia ${ }^{1}$, Lily Nathalia ${ }^{2}$, Anja Meryandini ${ }^{1 *}$ \\ ${ }^{I}$ Departemen Biologi, F MIPA IPB Jalan Raya Pajajaran 41 Bogor 16144 Tel 0251 - 377169 \\ Email: ameryandini@yahoo.com, *penulis untuk korespondensi \\ ${ }^{2}$ Balai Penelitian Veteriner, Jalan Martadinata, Bogor 16144
}

\begin{abstract}
Protease is one of the leather commercial enzymes which is widely used such in food processing, medicine and leather industry. Clostridium sp T11-3 was isolated from Tiu Jeruk River in Nusa Tenggara Barat. Sequence analysis of 16S rRNA indicated that Clostridium spp T11-3 was closely related to $C$. bifermentans. This isolate produced maximum protease activity after 18 hours of cultivation in liquid media. Protease of Clostridium spp 11-3 displayed maximum activity at $\mathrm{pH} 5$ and $60^{\circ} \mathrm{C}$ with casein as substrate. In the presence of $1 \mathrm{mM}$ divalent ion $\mathrm{Mg}^{2+}$ the enzym activity increased to 141 $\%$, while others ion divalent $\left(\mathrm{Ca}^{2+}, \mathrm{Zn}^{2+}, \mathrm{Cu}^{2+}, \mathrm{Fe}^{2+}\right.$, and $\left.\mathrm{Co}^{2+}\right)$ inhibited protease activity.
\end{abstract}

Key word: Clostridium spp T11-3, protease Exstracellular, divalent ion

Diterima : 15 Juli 2004, disetujui : 20 September 2005

\section{Pendahuluan}

Protease merupakan salah satu enzim komersial yang paling banyak dimanfaatkan oleh industri, antara lain pada industri keju, pengempukan daging, farmasi, penyamakan kulit, deterjen (Mc Kane \& Kandel, 1999, Collignan \& Montet, 1998, Rao et al., 1998). Disamping penggunaannya dalam bidang industri, kini protease mulai digunakan dalam bidang kesehatan sebagai terapi bagi penderita kanker paru-paru, lambung, ovari, serviks, dan kanker kolon. Protease juga digunakan secara bersamaan dengan terapi konvensional seperti operasi, kemoterapi dan radiasi (Murray, 2004).

Protease komersial yang dihasilkan oleh mikrob merupakan protease ekstraseluler. Data protease yang berasal dari bakteri anaerob masih sangat sedikit. Clostridium adalah bakteri anaerob yang bersifat gram positif, berbentuk batang dan membentuk endospora, dan mampu memproduksi protease jenis-jenis Clostridium yang telah berhasil diisolasi proteasenya diantaranya dari Clostridium acetobutylicum, C. perfringens, C. sporogenes, C. histolitycum dan C. bifermentans (Croux et al., 1990, Enggel et al., 2004).

Clostridium spp T11-3 merupakan salah satu galur dari lima galur yang memiliki indeks proteolitik yang cukup besar. Bakteri itu diisolasi dari sungai Tiu Jeruk, Nusa Tenggara Barat. Penelitian ini bertujuan untuk mengkarakterisasi protease yang dihasilkan oleh Clastridium spp T11-3.

\section{Metode Penelitian}

\section{Identifikasi isolat}

Isolat Clostridium spp T11-3 merupakan koleksi Laboratorium Mikrobiologi, Departemen Biologi FMIPA IPB yang diisolasi dari sungai Tiu Jeruk di Nusa Tenggara Timur. Isolat Clostridium $s p$ T11-3 dianalisis menggunakan 16S-rRNA bakteri Untuk amplifikasi sekitar $1500 \mathrm{pb}$ digunakan 2 primer spesifik F5 
TGGCTCAG 3') dan R5 (5' CCCGGGATCCAAGCTTAAGGAGGTATC CAGCC 3'). Kondisi PCR yang digunakan: pre-PCR $95^{\circ} \mathrm{C} 5$ menit; denaturasi $95^{\circ} \mathrm{C}, 30$ detik; penempelan primer $50^{\circ} \mathrm{C}, 30$ detik; pemanjangan primer $72^{\circ} \mathrm{C}, 2$ menit, dan pascaPCR $50^{\circ} \mathrm{C}, 5$ menit $72^{\circ} \mathrm{C} 5$ menit. Data sekuen gen 16S-rRNA dibandingkan dengan data yang ada pada Genebank. Analisis sekuen menggunakan program European Bioinformatics Institut (http://www.ebi.ac.uk).

\section{Produksi Protease}

Produksi protease dilakukan dalam botol bertutup ulir. Inokulum sebanyak $2 \%\left(\mathrm{OD}_{650 \mathrm{~nm}}\right.$ $=0.800$, yaitu $10^{8} \mathrm{sel} / \mathrm{ml}$ ) diinokulasikan $\mathrm{ke}$ dalam media produksi yang terdiri atas $\mathrm{Na}_{2} \mathrm{HPO}_{4} 0.8 \mathrm{~g} / \mathrm{l}, \mathrm{NaH}_{2} \mathrm{PO}_{4} 0.2 \mathrm{~g} / \mathrm{l}, \mathrm{NaCl}$ $4.5 \mathrm{~g} / \mathrm{l}, \mathrm{MgSO}_{4} 7 \mathrm{H} 2 \mathrm{O} 0.4 \mathrm{~g} / \mathrm{l}, \mathrm{CaCl}_{2} 2 \mathrm{H}_{2} \mathrm{O} 0.05$ $\mathrm{g} / \mathrm{l}$, sodium tioglikolat $0.4 \mathrm{~g} / \mathrm{l}$, ekstrak khamir $2.5 \mathrm{~g} / \mathrm{l}$, pepton $5 \mathrm{~g} / \mathrm{l}, \mathrm{NH}_{4} \mathrm{Cl} 1 \mathrm{~g} / \mathrm{l}$, glukosa $2 \mathrm{~g} / \mathrm{l}$, dan Tween $800.5 \mathrm{ml} / \mathrm{l}$ (Mac Farlane \& Mac Farlane 1992) dalam $1000 \mathrm{ml}$ akuades dan diinkubasi pada suhu $37^{\circ} \mathrm{C}$. Media produksi dijaga pada kisaran $\mathrm{pH}$ 7.0-7.5 dengan cara menambahkan beberapa tetes $\mathrm{NaOH} 5 \mathrm{M}$ selama masa pertumbuhan. Ekstrak kasar enzim diperoleh dengan disentrifugasi pada kecepatan 8000 g selama 20 menit pada suhu $4^{\circ} \mathrm{C}$.

Uji Aktivitas enzim dilakukan dengan metode Kulnitz yang dimodifikasi Walter (1994). Sebanyak $0.2 \mathrm{ml}$ ekstrak kasar enzim direaksikan dengan $1 \mathrm{ml}$ substrat kasein $2 \%$ dan $1 \mathrm{ml}$ Tris- $\mathrm{HCl} \mathrm{pH}$ 7.5, diinkubasi pada suhu $37^{\circ} \mathrm{C}$ selama 10 menit. Reaksi dihentikan dengan penambahan $2 \mathrm{ml}$ (TCA) Trichloroaceticacid $0.1 \mathrm{M}$, dan diinkubasi pada suhu ruang selama 10 menit. Selanjutnya suspensi disentrifugasi pada $8000 \mathrm{~g}$ selama 10 menit, pada $4^{\circ} \mathrm{C}$. Filtrat sebanyak $1.5 \mathrm{ml}$ direaksikan dengan $2 \mathrm{ml}$ pewarna Folin
Ciocalteu : $\mathrm{H}_{2} \mathrm{O}(1: 2)$ dan $5 \mathrm{ml} \mathrm{Na} 2 \mathrm{CO} 30.4 \mathrm{M}$, diinkubasi pada suhu ruang selama 20 menit, dan absorbansi dibaca pada panjang gelombang 578 nm. Pengukuran kadar protein ekstrak kasar enzim dilakukan menurut Bradford (1976).

\section{Karakterisasi Protease}

Ekstrak kasar enzim diujikan pada berbagai suhu inkubasi $\left(30-90{ }^{\circ} \mathrm{C}\right.$, dengan selang $10{ }^{\circ} \mathrm{C}$ ) dan berbagai $\mathrm{pH}$, yaitu $3.0-9.0$, dengan selang 0.5 unit untuk mengetahui kondisi optimum aktivitas protease. Penyangga yang digunakan ialah bufer sitrat fosfat untuk pH $3-6.5$, bufer Tris $\mathrm{HCl}$ untuk pH $7-8.5$ dan bufer glisin $\mathrm{NaOH}$ untuk $\mathrm{pH} 9$.

Enam jenis kation $\left(\mathrm{Ca}^{2+}, \mathrm{Zn}^{2+}, \mathrm{Cu}^{2+}\right.$, $\mathrm{Mg}^{2+}, \mathrm{Fe}^{2+}$, dan $\mathrm{Co}^{2+}$ ) yang berasal dari garam $\mathrm{CaCl}_{2}, \mathrm{ZnCl}_{2}, \mathrm{CuSO}_{4}, \mathrm{MgSO}_{4}, \mathrm{FeSO}_{4} \cdot 7 \mathrm{H}_{2} \mathrm{O}$, dan $\mathrm{CoCl}_{2}$ ditambahkan secara terpisah dengan konsentrasi akhir masing-masing sebesar $1 \mathrm{mM}$ dan $5 \mathrm{mM}$. Penambahan beberapa jenis kation divalen dilakukan untuk mengetahui pengaruh kation divalen terhadap aktivitas protease.

\section{Hasil dan Pembahasan}

\section{Identifikasi Isolat}

Dari 779 pasangan basa yang dianalisis menggunakan 16S-rRNA, Clostridium sp T113 memiliki tingkat kesamaan 94,3\% identik dengan Clostridium bifermentans.

\section{Produksi Protease}

Aktivitas protease yang diukur setiap 3 jam selama masa inkubasi 24 jam mencapai aktivitas maksimum pada jam ke-18 dengan aktivitas spesifik sebesar $0.1384 \quad \mathrm{U} / \mathrm{mg}$ (Gambar 1). 


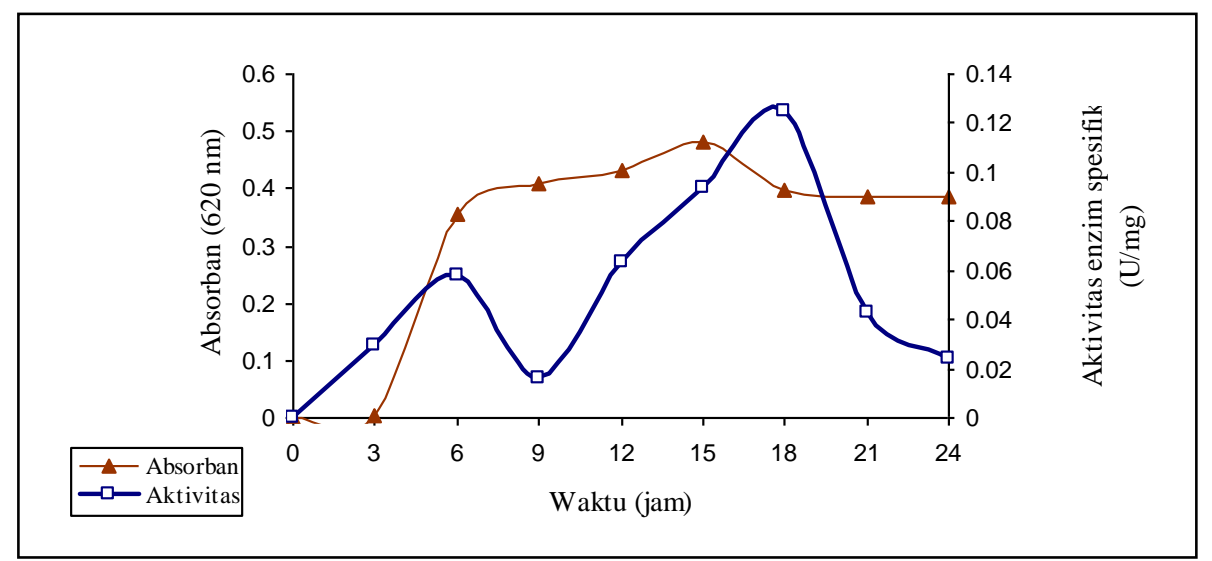

Gambar 1. Kurva pertumbuhan dan aktivitas spesifik protease Clostridium sp T11-3

Protease Clostridium sppT11-3 mencapai aktivitas maksimum pada suhu $60{ }^{\circ} \mathrm{C}$ dan $\mathrm{pH} 5$ (Gambar 2 dan 3). Suhu optimum Clostridium sppT11-3 berbeda dengan Clostridium bifermentans $\mathrm{R} 14-1-\mathrm{b}\left(50{ }^{\circ} \mathrm{C}\right)$ yang diisolasi dari rumen sapi di Bogor dan Clostridium lituseburense $\mathrm{Me} 2-3\left(30^{\circ} \mathrm{C}\right)$ yang diisolasi dari danau Meraran di NTB (Enggel et al., 2004, Meryandini 2005). Suhu optimum Clostridium spp T11-3 sama dengan aktivitas protease Bacillus subtilis PE-11 (Adinarayana et al., 2003), namun lebih rendah dari aktivitas protease Thermoactinomyces candidus yaitu 70 ${ }^{\circ} \mathrm{C}$ (Ignatova et al., 1994). Genus lain seperti Streptococcus reticuli dan Alcaligenes faecalis memiliki aktivitas proteasenya pada suhu $55{ }^{\circ} \mathrm{C}$ (Moormann et al., 1993, Thangam \& Rajkumar, 2002).

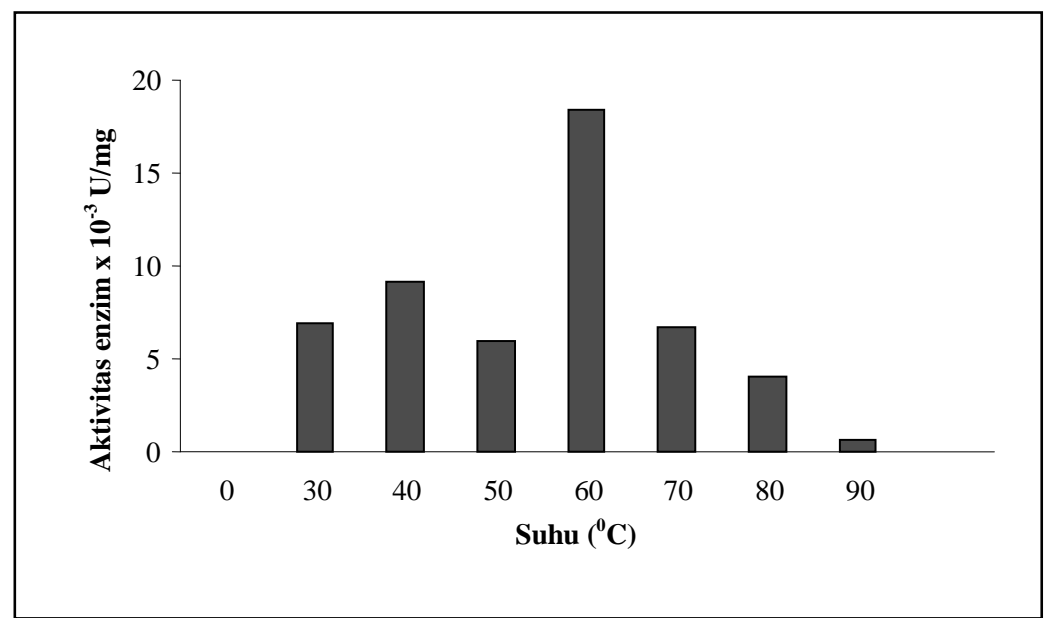

Gambar 2. Pengaruh suhu $\left({ }^{\circ} \mathrm{C}\right)$ terhadap aktivitas protease Clostridium spp T11-3 pada $\mathrm{pH} 7.5$

Penentuan kondisi $\mathrm{pH}$ optimum digunakan untuk menentukan golongan protease. Protease Clostridium spp T11-3 merupakan protease asam. Aktivitas protease tertinggi Clostridium spp T11-3 dicapai pada $\mathrm{pH} 5$, sedikit diatas aktivitas protease Saccharomyces cerevisiae yang aktif pada $\mathrm{pH}$ 4.8 (Roy et al., 2000). Aktivitas protease pada pH 5 juga dimiliki oleh Klebsiella oxytoca
(Tondo et al., 2004). Clostridium bifermentans R14-1-b dan Clostridium lituseburense Me2-3 memiliki pH optimum 7.5 (Enggel et al., 2004, Meryandini 2005). Protease asam dapat digunakan dalam industri makanan (pembuatan keju, pengempukan daging) dan pengelolaan kulit (Poza et al., 2003, Slokoska et al., 1999, Collignan \& Montet 1998). 


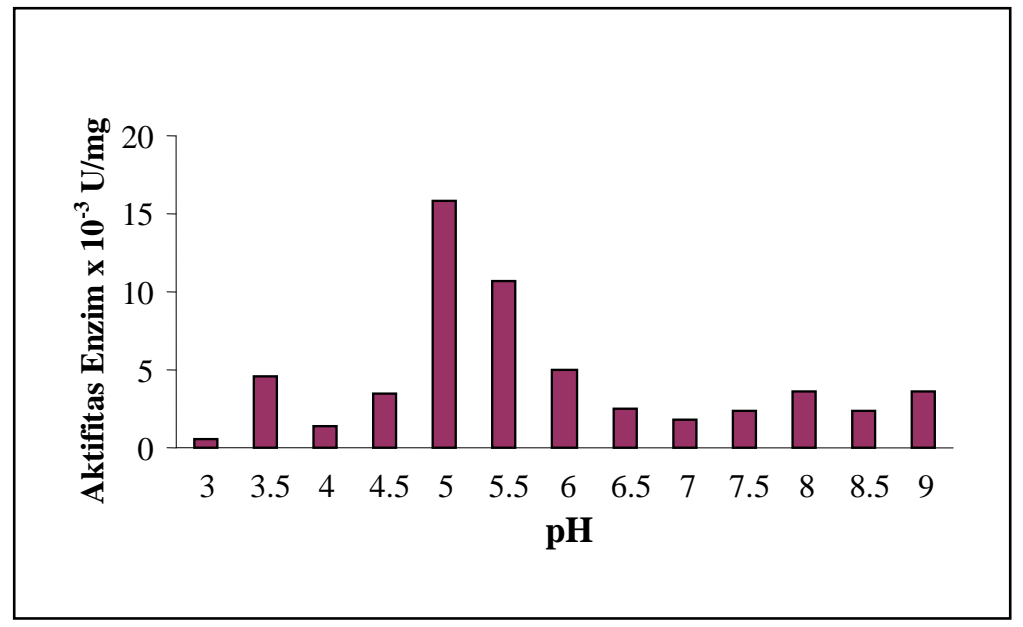

Gambar 3. Pengaruh $\mathrm{pH}$ terhadap aktivitas protease (U/mg) Clostridium sppT11-3 pada suhu $37^{\circ} \mathrm{C}$.

Penambahan $1 \mathrm{mM}$ kation divalen $\mathrm{Mg}^{2+}$ pada ekstrak kasar enzim meningkatkan aktivitas protease Clostridium spp T11-3 sebesar $141 \%$. Kation divalen lainnya memberikan penurunan aktivitas protease baik pada konsentrasi 1 mM maupun pada konsentrasi $5 \mathrm{mM}$ (Gambar 4). Penambahan 1 $\mathrm{mM}$ kation $\mathrm{Co}^{2+}, \mathrm{Zn}^{2+}, \mathrm{Fe}^{2+}$ dan $5 \mathrm{mM} \mathrm{Mg}{ }^{2+}$ menghambat aktifitas protease sehingga tidak terdeteksi.

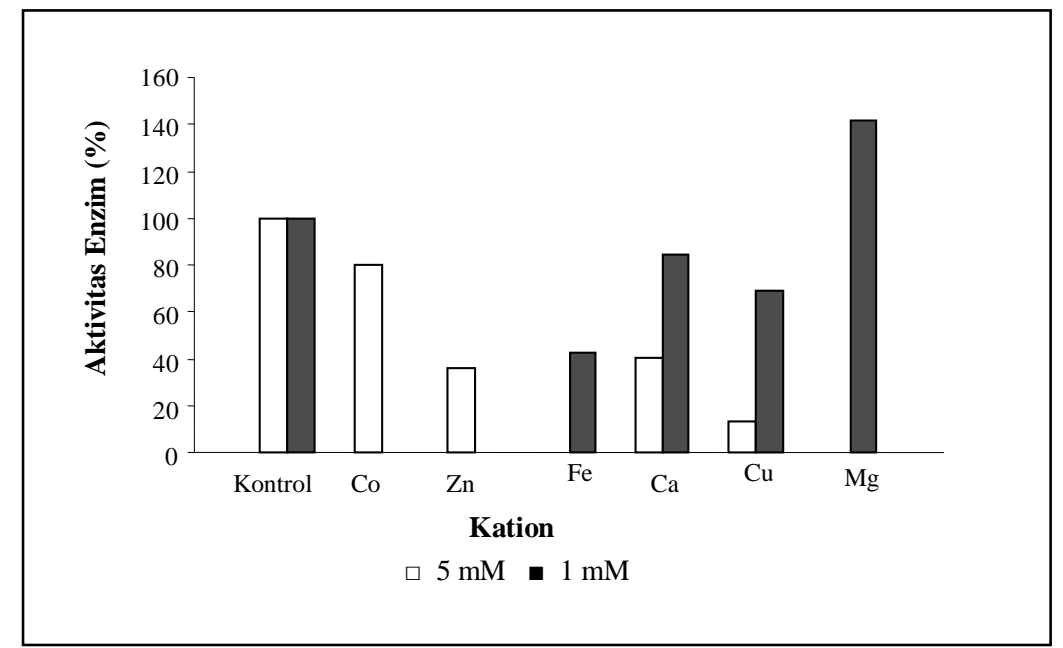

Gambar 4. Pengaruh kation divalen terhadap aktivitas protease Clostridium spp T11-3 pada pH 5, suhu $60{ }^{\circ} \mathrm{C}$.

Penambahan beberapa kation divalen memberikan pengaruh yang berbeda-beda terhadap aktivitas protease. Peningkatkan aktivitasnya protease Brevibacterium linens ATCC 9174, Yersinia ruckeri dan Bacillus subtilis $\mathrm{PE}-11$ membutuhkan ion $\mathrm{Ca}^{2+}$ dan $\mathrm{Mg}^{2+}$ (Rattray et al., 1995, Secades et al., 1999, Adinarayana et al., 2003), sedangkan protease $C$. bifermentans $\mathrm{R}$ 14-1-b membutuhkan ion $\mathrm{Fe}^{2+}$ (Enggel et al. 2004).
Protease $C$. lituseburense Me1-3 mempunyai aktivitas yang tinggi dengan penambahan logam $\mathrm{Co}^{2+} 5 \mathrm{mM}$ (Meryandini 2005). Keberadaan logam $\mathrm{Cu}^{2+}, \mathrm{Hg}^{2+}$ dapat menurunkan aktivitas protease Chryseobacterium sp galur Kr6 (Riffel et al. 2003), demikian juga dengan ion $\mathrm{Zn}^{2+}$, dan $\mathrm{Co}^{2+}$ menghambat aktivitas protease $C$. bifermentans R 14-1-b (Enggel et al., 2004). 


\section{Ucapan Terima Kasih}

\author{
Penelitian ini didanai oleh Penelitian Dasar \\ 2003 dengan kontrak $\mathrm{Nr}$ \\ 11/P2IPT/DPPM/PID/2003.
}

\section{Daftar Pustaka}

Adinarayana, K., Ellaiah, P. and Prasad, D.S. 2003. Purification and partial characterization of thermostable serine alkaline protease from a newly isolated Bacillus pumilus PE-11. Aaps Pharm Sci Tech 4:1-9

Bradford, M.M. 1976. A rapid and sensitive method for the quantitation of microgram quantities of protein utilizing the principle of protein dye binding. Anal Biochem 72:248-254.

Croux, C., Paquet, V., Gamo, G. and Soucaille, P. 1990. Pufication and characterization of acidolycin, an acidic metalloprotease produced by Clostridium acetobutylicum ATCC 824. Appl Environ Microbiol 50: 3634-3642.

Collignan, A. and Montet, D.1998. Tenderizing squid mantle by marination at different $\mathrm{pH}$ and temperature levels. Lebensm-Wiss u-Technol 31:673-679

Denizci, A.A., Kazan, D., Abeln, E.C.A. and Erarslan, A. 2004. Newly isolated Bacillus clausii GMBAE42: an alkaline protease producer capable to grow under higly alkaline conditions. J. Appl. Microbiol. 96:320 - 327

Enggel, J., Meryandini, A. and Natalia, L. 2004. Characterization of extracellular protease from Clostridium bifermentans R14-1-b. Mikrobiol. Ind. Vol. 9 No 1

Ignatova, Z., Gousterova, A., Spassov, G. and Nedkov, P. 1999. Isolation and partial characterization of extracellular keratinase from a wool degrading thermophilic actinomycete strain Thermoactinomyces candidus. Rev. Can. Microbiol. 45:217-222.

Lin, X., Lee, C., Casale, E.S. and Shih, J.C.H. 1992. Purification and characterization of a keratinase from a feather-degrading Bacillus licheniformis strain. Appl Environ. Microbiol. 58: $3271-3275$.

MacFarlane, G.T. and MacFarlane, S. 1992. Physiological and nutritional factor affecting synthesis of extracelluler metaloprotease by Clostridium bifermentans NCTC 2914. Appl Environt Microbiol. 58: 1195-1200.

Mc Kane, L. and Kandel, J. 1999. Microbiology Essential \& Application. Ed ke-2. USA: McGraw-Hill, Inc

Meryandini, A. 2005. Characterization of extracellular Clostridium lituseburense Me1-3 from
Meraran Lake in East Nusa Tenggara. Mikrobiol. Ind. Vol. 10 No 1 pp 45-47.

Moormann, M., Schlochtermeier, A. and Schrempf, H.1993. Biochemical characterization of a protease involved in the processing of a Streptomyces reticuli cellulase (Avicelase). Appl. Environ. Microbiol. 59: 1573 - 1578.

Murray, T. What are proteolytic enzyme. http://dr.murray.com/article/penzym e. [20 April 2004].

Poza, M., Sieiro, C., Careira,L., Barros-Velazquez, J. and Villa, T.G. 2003. Production and characterization of the milk-clotting protease of Myxococcus xanthus strain 422. J Ind Microbiol Biotechnol 30 (12): 691 - 698

Rao, M.B., Thanksale, A.M., Ghatge, M.S. and Desphande, V.V. 1998. Molecular and biotechnological aspects of microbial proteases. Microb Mol Biol Rev 62(3): 597635.

Rattray, F.P., Bockelmann, W. and Fox, P.F. 1995. Purification and characterization of an extracellular proteinase from Brevibacterium linens ATCC 9174. Appl Environt Microbial 61: 3454-3456.

Riffel, A., Lucas, F., Heib, P. and Brandelli, A. 2003. Characterization of a new keratinolytic bacterium that completely degrades native feather keratin. Arch Microbiol 179:258-265

Roy, M.K., Watanabe, Y. and Tamai, Y. 2000. Yeast protease B-digested skimmed milk inhibits angiotensin-I-converting-enzyme activity. Biotechnol. Appl. Biochem. 31: 95 - 100.

Secades, P., Alvares, B. and Guijarro, J.A. 1999. Purification and characterization of of an extracellular protease from the fish patogen Yersinia ruckeri and effect of cultur conditions of production. Appl Environ Microbiol 67: 3969-3975.

Slokoska, L., Angelova, M., Pashova, S., Petricheva, E. And Konstantinov, Ch. 1999. Production of acid proteinase by Humicola lutea 120-5 immobilized in mixed photo-cross-linked polyvinyl alcohol and calcium-alginate beads. Process Biochem 34: 73-76

Thangam, E.B. and Rajkumar, G.S. 2002. Purification and characterization of alkaline protease from Alcaligenes faecalis. Biotechnol Appl Biochem 35:149-154

Tondo, E.C., Lakus, F.R., Oliveira, F.A. and Brandelli, A. 2004. Identification of heat stable protease of Klebsiella oxytoca isolated from raw milk. Lett Appl Microbiol 38:146-150

Walter, H.E. 1994. Methode with haemoglobin casein and azocoll as substrate. Di dalam Bergmeyer HU, editor. Methode of Enzyme Analisys. Weinheim: VCH Verlaggessellchaft. 